CENTRE for ECONOMIC

$P$ E R F O R M A N C E

CEP Discussion Paper No 1084

October 2011

\title{
The Empirics of Firm Heterogeneity and International Trade
}

Andrew B. Bernard, J. Bradford Jensen, Stephen J. Redding and Peter K. Schott 


\begin{abstract}
This paper reviews the empirical evidence on firm heterogeneity in international trade. A first wave of empirical findings from micro data on plants and firms proposed challenges for existing models of inter- national trade and inspired the development of new theories emphasizing firm heterogeneity. Subsequent empirical research has examined additional predictions of these theories and explored other dimensions of the data not originally captured by them. These other dimensions include multi-product firms, offshoring, intra-firm trade and firm export market dynamics.
\end{abstract}

JEL Classifications: F10, F12, F14

Keywords: Heterogeneous firms, exporting, importing, productivity

This paper was produced as part of the Centre's Globalisation Programme. The Centre for Economic Performance is financed by the Economic and Social Research Council.

\title{
Acknowledgements
}

Bernard. Jensen and Schott thank the National Science Foundation (SES-0241474, SES0552029 and SES- 0550190) and Redding thanks Princeton University and the Centre for Economic Performance (CEP) for research support. This paper was prepared for the Annual Review of Economics. We are grateful to Peter Neary for helpful comments and suggestions. The research in this paper was conducted while Bernard, Jensen, Redding and Schott were Special Sworn Status researchers of the U.S. Census Bureau at the Boston Research Data Center and Center for Economic Studies. Research results and conclusions expressed are those of the authors and do not necessarily reflect the views of the Census Bureau, the NBER, or any other institution to which the authors are affiliated.

Andrew B. Bernard is Professor of International Economics, Tuck School of Business at Dartmouth and NBER. J. Bradford Jensen is an Associate Professor of International Business and Economics at the McDonough School of Business at Georgetown University, Washington, DC, a senior fellow at the Peterson Institute for International Economics, and a research associate of NBER. Stephen J. Redding is Director of the Globalisation Programme at the Centre for Economic Performance and Professor of Economics in the Economics Department at the London School of Economics. Peter K. Schott is Professor of Economics, Yale School of Management and NBER.

Published by

Centre for Economic Performance

London School of Economics and Political Science

Houghton Street

London WC2A 2AE

All rights reserved. No part of this publication may be reproduced, stored in a retrieval system or transmitted in any form or by any means without the prior permission in writing of the publisher nor be issued to the public or circulated in any form other than that in which it is published.

Requests for permission to reproduce any article or part of the Working Paper should be sent to the editor at the above address.

(C) A. B. Bernard, J. B. Jensen, S. J. Redding and P. K. Schott, submitted 2011 


\section{Introduction}

Research in international trade has changed dramatically over the past fifteen years as its focus has shifted from industries and countries to firms and products. This transformation was instigated by the emergence of a wide range of "micro"-datasets exhibiting sharp variation in firm outcomes and attributes, even within narrow industries. Models developed in reaction to this challenge both rationalize this heterogeneity and offer new insight into the ways in which economies respond to international trade. For example, the well-known gravity equation relationship between aggregate trade and distance is largely accounted for by the extensive margin of the number of heterogeneous firms and products participating in trade rather than the intensive margin of the amount traded per firm and product.

One of the most striking features of the microdata is that firm participation in international trade is exceedingly rare. Researchers find that exporters and importers represent just a tiny fraction of producers across many developed and developing economies. This participation is far from random. Indeed, the same studies find that exporters and importers are larger, more productive, more skill- and capital-intensive, and pay higher wages prior to their entry into international markets than non-trading firms. These facts suggest self-selection: exporters are more productive, not necessarily as a result of exporting, but because only the most productive firms are able to overcome the costs of entering export markets. The most successful model of such selection is the seminal Melitz (2003) model, which has dominated recent research in the field. The key insight of that model is that micro-heterogeneity influences aggregate outcomes. When trade policy barriers or transportation costs fall, high-productivity exporting firms survive and expand while lower-productivity non-exporting firms shrink or exit. This reallocation of economic activity across firms raises aggregate productivity, an effect of globalization that was largely neglected in previous theories of international trade based on comparative advantage and consumer love of variety.

Much of recent theoretical research in international trade has focused on generalizing or elaborating on this basic model of selection. Studies have explored the interaction between comparative advantage and heterogeneous firms (Bernard et al. 2007a), variable mark-ups and market size (Melitz \& Ottaviano 2008), country asymmetries (Arkolakis et al. 2008), multi-product firms (Bernard et al. 2011, Eckel \& Neary 2010, Mayer et al. 2011), the decision whether to organize production activities within or beyond the boundaries of the firm (Antràs \& Helpman 2004, 2008), managerial hierarchies within the firm (Caliendo \& Rossi-Hansberg 2011), labor market frictions (Amiti \& Davis 2011, Egger \& Kreickemeier 2009, Helpman and Itskhoki 2010, and Helpman et al. 2011), and financial constraints (Chaney 2005, Manova 2011), among other issues. ${ }^{1}$

We begin by reviewing the empirical challenges to traditional theories of international trade that emerged from micro data on plants and firms (Section 2). We next briefly discuss the development of theories of heterogeneous firms that have shaped much subsequent empirical research (Section 3). More recently, the

\footnotetext{
${ }^{1}$ For reviews of the theoretical literature on heterogeneous firms and trade, see Helpman (2006) and Redding (2010).
} 
availability of microdata on individual trade transactions within the firm has stimulated empirical research on a whole host of new topics, including the extensive and intensive margins of trade (Section 4), multiproduct firms (Section 5), firm importing (Section 6), product quality (Section 7), intermediaries (Section 8), foreign direct investment (Section 9), intra-firm trade (Section 10), labor markets (Section 11), and firm export market dynamics (Section 12).

\section{Empirical Challenges to Existing Trade Theories}

Traditional (or "old") theories of international trade emphasize comparative advantage - that is variation in opportunity costs of production across countries and industries - as the basis for international trade. In these theories, international commerce takes the form of inter-industry trade, where countries export goods in one set of industries and import goods in another set of industries. More recent (or "new") theories of international trade instead focus on increasing returns to scale and consumer love of variety as the basis for international trade, as in Krugman (1980), Helpman (1981) and Ethier (1982). These theories provide a natural explanation for intra-industry trade, where countries both export and import goods within the same industry. The two theories were combined within the integrated equilibrium approach of Helpman \& Krugman (1985). When suitably augmented to allow for technology differences and cross-country variation in factor prices, they provided a relatively successful explanation for patterns of trade across countries and industries, as reviewed in Helpman (1999). A key simplification in this theoretical literature was the assumption of a representative firm within each industry. With the increased availability of micro datasets on firms and plants from the late 1980s and 1990s onwards, it became clear that there was in fact vast heterogeneity across producers within industries, in terms of size, productivity, capital and skill-intensity, and wages. Furthermore an emerging empirical literature began to explore the idea that this heterogeneity was systematically related to trade participation in ways that could be influential for aggregate outcomes.

\subsection{Export Participation}

Bernard \& Jensen (1995) present evidence on U.S. manufacturing showing that typically a minority of plants within an industry export. As illustrated in Table 1, which is taken from Bernard et al. (2007b) and uses data from the 2002 U.S. Census of Manufactures, the overall share of U.S. manufacturing firms that export is relatively small at 18 percent (column 3). But there is considerable variation in export market participation rates across industries within manufacturing: the share of exporters ranges substantially, from 38 percent in Computer and Electronic Products to only 8 percent in Apparel. These exporting firms also ship a relatively small share of their total shipments abroad. As shown in column 4, the average share of shipments exported is 14 percent for the manufacturing sector as a whole. But again there is substantial variation exists across industries: from 21 percent in Computers to 7 percent in Beverages. While the results here use U.S. data, 
similar findings have emerged for a wide range of other countries, as summarized for example in Mayer \& Ottaviano (2007) and World Trade Organization (2008).

\subsection{Exporter Characteristics}

The first wave of microdata research demonstrated that not only is exporting rare but exporters are systematically different from non-exporters. Bernard \& Jensen (1995) show that among U.S. manufacturing plants, exporters are larger, more skill intensive, more capital intensive, and more productive. Table 2, also from Bernard et al. (2007b), highlights these differences for manufacturing firms. Each row of the table summarizes the average percent difference between exporters and non-exporters for a particular characteristic.

As shown in the first column, there are substantial mean differences between exporters and non-exporters. On average, exporting firms are larger in employment and sales, more productive, and use a different input mix. Since export participation is correlated with industry characteristics, the inclusion of industry effects in the second column typically reduces the magnitude of these coefficients. But exporters remain different from non-exporters even within the same disaggregated industry: they are 97 percent larger in employment and 108 per cent larger in shipments; they are more productive by 11 per cent for value-added per worker and 3 per cent for total factor productivity; they also pay higher wages by around 6 percent. Finally, exporters are relatively more capital- and skill-intensive than non-exporters by approximately 12 and 11 percent, respectively.

While the correlation between firm size and exporting accounts for some of the differences between exporters and non-exporters, they remain even after controlling for log employment, as shown in the third column. Qualitatively similar results have been found for many other countries and time periods. ${ }^{2}$

The finding that U.S. exporters are more capital- and skill-intensive is consistent with "old" trade theory forces of comparative advantage being at work within industries. If a firm's factor intensity reflects the nature of the products it supplies, then firms which are more capital- and skill-intensive are supplying products that are more consistent with U.S. comparative advantage (Bernard et al. 2006b).

More difficult to square with old trade theory concepts of comparative advantage are empirical findings that exporters are also more capital- and skill-intensive in developing countries, which are plausibly abundant in unskilled labor (Alvarez \& Lopez, 2005). If exporting firms in these countries were supplying products consistent with comparative advantage, they would be labor-intensive rather than capital- and skill-intensive. Potential explanations for findings that exporters are more capital- and skill-intensive in both developed and developing countries include technology-skill complementarity, as explored in Burstein \& Vogel (2010) and Harrigan \& Resheff (2011), and sorting by product quality within industries as in Verhoogen (2008).

\footnotetext{
${ }^{2}$ Similar differences in performance are observed between firms shipping to remote versus proximate locations within the U.S., as shown in Holmes \& Stevens (2010).
} 


\subsection{Sunk Costs and Selection into Exporting}

The finding that exporters are more productive than non-exporters raises the question of the direction of causality: does high productivity induce firms to self-select into export markets or does exporting cause productivity growth through "learning by exporting." An extensive body of research for many industries and countries confirms that high productivity precedes entry into export markets. These findings are suggestive of sunk costs of entry into export markets that only the most productive firms find it profitable to incur, as emphasized in Roberts \& Tybout (1997). Whether there is also learning by exporting is less clear. Early studies by Clerides et al. (1998) using data for Mexico, Colombia and Morocco and Bernard \& Jensen (1999) using U.S. data found no evidence of differences in productivity growth between exporters and non-exporters. Most research confirms these findings, however, some studies have found evidence of productivity improvements following export market entry, such as Van Biesebroeck (2005) and de Loecker (2007). Other recent research has provided evidence that export market entry may increase the return to other complementary investments such as technology adoption, as examined theoretically in Constantini and Melitz (2008) and shown empirically in Bustos (2011), Lileeva \& Trefler (2010) and Aw et al. (2011).

\subsection{Trade Liberalization, Reallocation, and Productivity Growth}

Empirical analyses using microdata on plants and firms reveal new channels through which trade liberalization can affect the aggregate economy. Beyond the effects of the expansion in the range of product varieties available to consumers, there exists the potential for within-industry productivity growth arising from decreasing trade costs. Trade liberalization reforms are typically accompanied by the contraction and exit of low-productivity firms and the expansion and entry into export markets of high-productivity firms. This reallocation of resources within industries raises average industry productivity.

Additionally, trade liberalization can have a "pro-competitive" effect in reducing mark-ups of price over marginal cost, so that trade liberalization reduces average prices through both lower average costs and lower average mark-ups. These reductions in average prices in turn provide sources of welfare gain.

In the context of the Chilean trade liberalization, Pavcnik (2002) finds that roughly two-thirds of the 19 percent increase in aggregate productivity is due to the relatively greater survival and growth of highproductivity plants. A similar pattern of results is found in a large number of studies of trade liberalization reforms in developing countries, as surveyed in Tybout (2003). Within-industry reallocations of resources in these studies typically dominate cross-industry reallocations of resources.

One concern is that trade liberalization often occurs as part of a wider package of reforms. However, similar patterns of productivity gains from the expansion of high-productivity exporting firms have been found in response to reductions in trade barriers in both Canada (Trefler, 2004) and the United States (Bernard et al. 2006a). For example, Trefler (2004) finds effects of Canadian tariff reductions on industry productivity 
that are roughly twice as large as those on plant productivity, implying market share reallocations favoring high-productivity plants.

Another source of aggregate productivity growth following trade liberalization is improvements in productivity within plants or firms. In Pavcnik (2002), around one-third of the increase in aggregate productivity following the Chilean liberalization was due to within-plant productivity gains. Similarly, in Trefler (2004), the Canada-U.S. Free Trade Agreement is found to raise the labor productivity of Canadian manufacturing plants by 7.4 percent or by an annual compound growth rate of 0.93 percent. These improvements in plant or firm productivity may be themselves the result of reallocations across disparate economic activities within the plant or firm, as discussed further below.

\section{$3 \quad$ Heterogeneous Firm Theories}

The empirical challenges to old and new trade theory from microdata have led to the development of new theories of firm heterogeneity and international trade. These theories not only account for the features of disaggregated trade data noted above, but also yield additional predictions that have been the subject of further empirical work. The seminal study of Melitz (2003) introduces firm heterogeneity into Krugman's (1980) model of intra-industry trade to yield a tractable and flexible framework that has become a standard platform for analyzing a host of issues in international trade. ${ }^{3}$

In Melitz (2003), there is a competitive fringe of potential firms who can enter an industry by paying a fixed entry cost which is thereafter sunk. Potential entrants face ex ante uncertainty concerning their productivity. Once the sunk entry cost is paid, a firm draws its productivity from a fixed distribution and productivity remains fixed thereafter. Firms produce horizontally differentiated varieties within the industry under conditions of monopolistic competition. The existence of fixed production costs implies that firms drawing a productivity level below the "zero-profit productivity cutoff" would make negative profits and therefore exit the industry. Fixed and variable costs of exporting ensure that only those active firms that draw a productivity above a higher "export productivity cutoff" find it profitable to export. ${ }^{4}$

In this model, a symmetric reduction in trade barriers between all countries has a number of implications for industry equilibrium. High-productivity exporting firms experience increased revenue through greater export market sales. The most productive non-exporters now find it profitable to enter export markets, thereby increasing the fraction of exporting firms. In contrast, low productivity firms exit and there is a contraction in the revenues of surviving firms that only serve the domestic market. Each of these responses

\footnotetext{
${ }^{3}$ An alternative framework for modeling firm heterogeneity is Bernard et al. (2003), which considers Bertrand competition in the stochastic multi-country Ricardian model of trade of Eaton \& Kortum (2002). Another approach is pursued in Yeaple (2005), in which firms are ex ante identical, but firm heterogeneity emerges ex post through the endogenous allocation of heterogeneous workers across firms.

${ }^{4}$ For empirical evidence of sunk costs of exporting, see Roberts \& Tybout (1997), Bernard \& Jensen (2004), and Das et al. (2007).
} 
reallocates resources towards high-productivity firms and raises aggregate productivity through a change in industry composition.

This theoretical framework addresses a number of the empirical challenges from microdata. Together firm heterogeneity and fixed exporting costs imply that only some firms export and these exporters are more productive than non-exporters. The productivity advantage of exporting firms reflects self-selection into export markets rather than learning by exporting. Finally, the self-selection of firms into export markets ensures that trade liberalization has uneven effects on low and high-productivity firms and hence raises aggregate productivity through a change in firm composition.

While the assumption of constant elasticity of substitution (CES) preferences in Melitz (2003) ensures constant firm mark-ups of price over marginal cost, Bernard et al. (2003) and Melitz \& Ottaviano (2008) develop models of firm heterogeneity in which mark-ups endogenous and trade liberalization can have a pro-competitive effect in reducing prices through lower mark-ups over marginal cost. In models with variable elasticities of substitution, firms with different productivities charge different mark-ups in a given market and a firm with a given productivity charges different mark-ups in the domestic and export markets. Using Slovenian data, De Loecker \& Warzynski (2011) provide evidence of differences in mark-ups between exporters and non-exporters and discusses the implications of such variable mark-ups for estimated productivity differences between exporters and non-exporters.

In Bernard et al. (2007a), heterogeneous firms are integrated into the standard trade paradigm of Helpman \& Krugman (1985). The resulting framework simultaneously explains why some countries export more in certain industries than in others (endowment-driven comparative advantage), why two-way trade is observed within industries (firm-level horizontal product differentiation combined with increasing returns to scale), and why, within industries, some firms export and others do not (self-selection driven by trade costs). Consistent with the empirical findings reported in Table 1, the fraction of exporting firms and the share of exports in firm shipments vary systematically with comparative advantage.

\section{Gravity and the Extensive and Intensive Margins}

One of the most successful empirical relationships in economics is the gravity equation, which relates the value of total bilateral trade between countries to their economic mass and the variable trade costs between them. Under the assumption that firm productivity is Pareto distributed, the Melitz (2003) model yields a gravity equation for total bilateral trade flows, as shown in Chaney (2008) and Arkolakis et al. (2008). ${ }^{5}$ One remarkable feature of this gravity equation is that the elasticity of trade flows with respect to variable trade costs depends not on the elasticity of substitution between firm varieties but rather on the shape parameter

\footnotetext{
${ }^{5}$ For empirical evidence that the Pareto distribution provides a reasonable approximation to the observed distribution of firm sizes, see for example Axtell (2001).
} 
of the Pareto distribution for productivity.

The intuition for this result can be garnered by noting that aggregate bilateral trade between any two countries $\left(X_{i j}\right)$ can be decomposed into the extensive margin of the number of exporting firms $\left(M_{i j}\right)$ and the intensive margin of average firm exports conditional on exporting $\left(X_{i j} / M_{i j}\right)$ :

$$
X_{i j}=M_{i j}\left(\frac{X_{i j}}{M_{i j}}\right) .
$$

In the Melitz model, an increase in variable trade costs has two offsetting effects on the intensive margin. ${ }^{6}$ On the one hand, higher variable trade costs reduce the value of exports of a given exporter, which reduces average firm exports. On the other hand, higher variable trade costs imply that some exporters who were previously close to the productivity threshold for exporting can no longer generate sufficient variable profits to cover the fixed costs of exporting and exit the export market. Since these exiting exporters have smaller export values than surviving exporters, this raises average firm exports through a change in composition. In the special case of a Pareto distribution, these two effects exactly offset one another, leaving the intensive margin independent of variable trade costs. As a result, variable trade costs only affect bilateral trade through the extensive margin, and the elasticity of this extensive margin with respect to variable trade costs is determined by the shape parameter of the Pareto distribution for productivity.

The special case of the Melitz (2003) model with a Pareto distribution for productivity lies within the class of theoretical models considered by Arkolakis et al. (2011a), in which a country's share of trade with itself is a sufficient statistic for the welfare gains from opening the closed economy to trade. While empirical studies have sought to quantify the contributions of particular sources of welfare gains, such as product variety in Broda \& Weinstein (2006), this theoretical analysis implies that the various sources of welfare gains are related to one another in general equilibrium and that the overall effect of trade on welfare can be determined simply from a country's share of trade with itself. ${ }^{7}$

A key implication of the Melitz (2003) model is that the extensive margin of the number of exporting firms should vary systematically with export market size, since in larger markets firms of lower productivity can generate sufficient variable profits to cover the fixed costs of exporting. Using French export data by firm and destination market, Eaton et al. (2004, 2011a) establish this and a number of other empirical regularities. First, the number of French firms selling to a market (relative to French market share) increases with market size according to an approximately log linear relationship. Second, this pattern of firm export market participation exhibits an imperfect hierarchy, where firms selling to less popular markets are more likely to sell to more popular markets, but do not always do so. Third, export sales distributions are

\footnotetext{
${ }^{6}$ We define the intensive margin as average firm exports conditional on exporting because it facilitates the decomposition of average exports in (1) and has a straightforward empirical implementation. Chaney (2008) instead defines the intensive margin as exports of a given firm to a given destination, in which case the intensive margin is unaffected by composition.

${ }^{7}$ See also Atkeson and Burstein (2010) for an analysis of how the various sources of welfare gain are related to one another in general equilibrium.
} 
remarkably similar across markets of very different size and extent of French participation. While the upper tail of these distributions is approximately Pareto distributed, there are departures from a Pareto distribution in the lower tail where small export shipments are observed. Fourth, average sales in France are higher for firms selling to less popular foreign markets and to more foreign markets.

To explain these empirical regularities, Eaton et al. (2011a) consider an augmented version of the Melitz model with a Pareto productivity distribution. To generate departures from a Pareto distribution of export sales in the lower tail where small export shipments are observed, the fixed costs of entering each export market are allowed to vary endogenously with a firm's choice of the fraction of consumers within that market to serve, as in the marketing costs formulation of Arkolakis (2010). To incorporate imperfect hierarchies of markets, the fixed costs of entering export markets are assumed to be subject to an idiosyncratic shock for each firm and destination market as well a common shock for each destination market. To allow for idiosyncratic variation in export sales conditional on entering a given export market for firms with a given productivity, demand is also subject to an idiosyncratic shock for each firm and destination market. While a firm's decision to enter an export market depends on a composite of the market entry and demand shocks, a firm with a given productivity can enter a market because of a low entry shock and yet still have low sales in that market because of a low demand shock.

The properties of the model depend on five key parameters: (i) a composite parameter that includes both the elasticity of substitution and the Pareto shape parameter, (ii) the convexity of marketing costs, (iii) the variance of demand shocks, (iv) the variance of entry shocks, and (v) the correlation between demand and entry shocks. Eaton et al. (2011a) use simulated method of moments to estimate these parameters using moments of the French export data by firm and destination market. The five parameters are precisely estimated and the parameterized model is shown to provide a good fit to the observed data. For the estimated parameter values, firm productivity accounts for around half of the observed variation across firms in export market participation, but explains substantially less of the variation in exports conditional on entering a market.

Given the estimated parameter values, the model can be used to examine counterfactuals, such as a 10 percent reduction in bilateral trade barriers for all French firms. In this counterfactual, total sales by French firms rise by around $\$ 16$ million, with most of this increase accounted for by a rise in sales of the top decile of firms of around $\$ 23$ million. In contrast, every other decile of firms experiences a decline in sales, with around half of the firms in the bottom decile exiting. Taken together, these results suggest that the intra-industry reallocations emphasized by theories of heterogeneous firms and trade can be quantitatively large, even for empirically reasonable changes in trade frictions. ${ }^{8}$

\footnotetext{
${ }^{8}$ Other quantitative analyses of models of firm heterogeneity and trade include the study of trade integration in Corcos et al. (2010), the analysis of the impact of China's productivity growth on world welfare in Hsieh \& Ossa (2010), and the investigation of patterns of trade in Bangladesh's apparel sector in Cherkashin et al. (2010).
} 
Heterogeneous firm theories also shed light on the prevalence of zeros in bilateral trade flows. Using data on trade between 158 countries from 1970-97, Helpman et al. (2008) find that around one half of the country pairs do not trade with one another. Motivated by this feature of the data, they develop a multi-country version of the Melitz (2003) model, in which firm productivity is drawn from a truncated Pareto distribution. In this framework, no firm exports between a pair of countries if the productivity threshold for exporting exceeds the upper limit of the productivity distribution in each country. Estimating a gravity equation derived from the model, they show that controlling for both the non-random selection of positive trade flows and the extensive margin of exporting firms has quantitatively important implications for estimates of the effects of standard trade frictions on trade flows. Of these two corrections, controlling for the extensive margin of the number of heterogeneous firms that export is quantitatively more important than controlling for the non-random selection of positive trade flows. ${ }^{9}$

Although most research on heterogeneous firms and trade assumes a continuum of firms, Eaton et al. (2011b) argue that the existence of a finite number of firms provides an alternative potential explanation for zero bilateral trade flows. Even if the productivity distribution is unbounded from above, with a finite number of firms there is a positive probability that no firm draws a productivity above the threshold for exporting between a pair of countries.

\section{Multi-product Firms}

One of the striking feature of international trade data is the extent to which international trade is concentrated in the hands of a few firms. As reported in Bernard et al. (2009a), the top 1 percent of firms account for around 90 percent of the value of U.S. trade, even though they account for only around 15 percent of employment. Similar levels of concentration are observed in other countries, as summarized in World Trade Organization (2008).

One reason why international trade is so concentrated is that larger exporters not only export more of a given product to a given destination than smaller exporters, but also export more products to more destinations. Table 3, from Bernard et al. (2007b), reports the distribution of exporters, export value and employment by the number of products and export destinations. Around 40 percent of exporting firms export a single product to a single destinations (panel A), but these firms account for less than 1 percent of export value (panel B). In contrast, the 12 percent of firms that export more than five products to more than five destinations account for more than 90 percent of export value.

To make sense of firms' decisions over the extensive margins of products and destinations, Bernard et al. (2011) develop a model of multi-product, multi-destination firms that is a generalization of Melitz's (2003)

\footnotetext{
${ }^{9}$ Santos Silva and Tenreyro (2006) consider an alternative approach to zero trade flows using the Poisson fixed effects estimator.
} 
framework. In order to enter, firms incur a sunk entry cost, which reveals their ability. Firms then choose among a continuum of products and many export markets. Firm profitability depends upon the interaction of firm ability, which is common across products, and firm-product attributes, which are idiosyncratic across products and possibly also across export destinations. Firms face fixed costs in serving each market and in supplying each product to each market. Higher ability firms can generate sufficient variable profits to cover the product fixed cost at a lower value of product attributes and supply a wider range of products to each market. For sufficiently low values of firm ability, the excess of variable profits over product fixed costs in the small range of profitable products does not cover the fixed cost of serving the market and therefore the firm does not supply the market. The lowest-ability firms exit, intermediate-ability firms serve only the domestic market and the highest ability firms export. Within exporters, products with the worst attributes are supplied only to the domestic market, while products with the best attributes are exported to the largest number of markets.

While the standard heterogeneous-firm model emphasizes selection across firms, this model also emphasizes selection within firms. Selection within firms provides a potential rationale for the effects of trade liberalization on within-firm productivity found in the empirical studies discussed above, since trade liberalization induces firms to drop their least successful products with low revenue productivity. Using data from the Canada-U.S. Free Trade Agreement (CUSFTA), Bernard et al. (2011) and Baldwin \& Gu (2009) provide empirical evidence of product rationalization following trade liberalization.

The extensive margins highlighted by models of multi-product firms have important implications for the mechanisms underlying aggregate economic relationships. Aggregate bilateral trade between any two countries $\left(X_{i j}\right)$ can be decomposed into the extensive margin of the number of firm-product observations with positive exports $\left(O_{i j}\right)$ and the intensive margin of average firm-product exports conditional on positive trade $\left(\bar{x}_{i j}=X_{i j} / O_{i j}\right)$ :

$$
X_{i j}=O_{i j} \bar{x}_{i j}, \quad \bar{x}_{i j} \equiv\left(\frac{X_{i j}}{O_{i j}}\right),
$$

where the number of firm-product observations with positive trade can be decomposed in turn into the extensive margins of the number of exporting firms $\left(M_{i j}\right)$, the number of exported products $\left(N_{i j}\right)$ and a density term $\left(D_{i j}=O_{i j} /\left(M_{i j} N_{i j}\right)\right)$ that captures the extent to which each firm exports each product:

$$
O_{i j}=M_{i j} N_{i j} D_{i j}, \quad D_{i j} \equiv\left(\frac{O_{i j}}{M_{i j} N_{i j}}\right) .
$$

Table 4 reports the results of estimating gravity equations for aggregate U.S. exports and each of the extensive and intensive margins in (2) and (3). The table is taken from Bernard et al. (2011) and destination market size and variable trade costs are proxied using destination market GDP and geographical distance respectively. The well-known negative effect of distance on aggregate bilateral trade (column 1) is entirely accounted for by the extensive margin of the number of firm-product observations with positive trade (column 
3). In contrast, distance has a positive but statistically insignificant effect on the intensive margin of average exports per firm-product conditional on positive trade (column 2). The extensive margins of the number of exporting firms and the number of exported products both decline with distance (columns 4 and 5 ). The opposite is true of density, because each firm is active in a limited subset of products, which implies that the number of firm-product observations with positive trade $\left(O_{i j}\right)$ increases less than proportionately than the number of firms times the number of products $\left(M_{i j} N_{i j}\right)$.

The theoretical model discussed above provides a natural explanation for these empirical findings. A reduction in variable trade costs lowers product prices in each export market which increases revenue and variable profits. Reductions in variable trade costs raise aggregate exports through the share of products exported to a given country by incumbent exporters (within-firm product extensive margin), an increase in the average number of countries to which a given product is supplied by incumbent firms (within-firm country extensive margin) and lower-ability firms that previously only served the domestic market enter export markets (the across-firm extensive margin). In contrast, selection within firms implies that reductions in variable trade costs have ambiguous effects on the intensive margin of average exports per firm-product, because they increase exports of a given firm and product, but induce entry into export markets of firms and products with smaller export values.

A growing theoretical and empirical literature in international trade has investigated a variety of implications of multi-product, multi-destination firms. While early contributions such as Ottaviano \& Thisse (1999) and Allanson \& Montagna (2005) modeled firms and products symmetrically, more recent research has explored the idea that firms have core competences. Eckel \& Neary (2010) consider a model of flexible manufacturing where each firm faces rising marginal costs in producing products further from its core competence. Firms are large relative to the market and hence face a cannibalization effect, where introducing additional products diminishes the demand for the firm's existing products. ${ }^{10}$ Javorcik et al. (2010) consider an augmented version of this model, in which firms can make endogenous investments in the quality of each product and in their overall brand. Using Mexican trade transactions data, they provide empirical evidence in support of the model's key predictions for the relationship between product prices and sales rank within the firm.

Other recent research has concentrated on monopolistically-competitive models of multiple-product firms without cannibalization effects. In Mayer et al. (2011), firms face a product ladder, where productivity/quality declines discretely for each additional variety produced. Together with variable mark-ups, this generates the prediction that firm sales are more skewed towards core competences in more competitive markets. French export data provide strong empirical support for this prediction of the model. In Arkolakis \& Muendler (2010), firms face declining productivity for each additional variety supplied to a market and

\footnotetext{
${ }^{10}$ See also Feenstra \& Ma (2008) and Dhingra (2010).
} 
market entry costs that are increasing in the number of varieties supplied to a market. Using Brazilian trade transactions data, they present evidence in support of the model's prediction of a positive relationship between the number of products that a firm exports to a market and average exports per product. In contrast, in Nocke and Yeaple (2006), firms with higher organizational capability produce more products and have higher marginal costs for all products, which generates a negative relationship between firms' extensive and intensive margins.

While most of the above research concentrates on the determinants of the products and destinations supplied by multi-product firms at a given point time, there is evidence that product market entry and exit within surviving firms is influential for firm, industry and aggregate dynamics over time. Using U.S. Census of Manufactures data, Bernard et al. (2010a) find that around one half of surviving U.S. firms add and/or drop products from their existing range every five years, and the contribution of these added and dropped products to aggregate output is of around the same magnitude as the contribution of firm entry and exit. ${ }^{11}$ Consistent with a natural generalization of models of industry dynamics to incorporate selection with firms, the probability that a product is dropped within a surviving firm exhibits the same pattern of age and scale dependence as the probability that a firm exits. Taken together, these findings suggest that reallocation may be even more important than hitherto thought, in so far as it occurs across products within firms as well as across firms.

\section{Firm Importing}

The early empirical literature on firm heterogeneity in international trade concentrated almost exclusively on firm export behavior, since only exporting information was recorded in censuses of domestic production or manufacturing. More recent work using firm-level trade transaction data has begun to examine heterogeneity in firm import behavior.

Firm importing displays many of the same features as firm exporting. Bernard et al. (2007b) find that, for U.S. manufacturing firms, importing is somewhat rarer than exporting and there is substantial variation across industries. The shares of exporting and importing firms are significantly positively correlated (0.87) across industries. Around 41 percent of exporters also import while 79 percent of importers also export. The share of export-only firms is positively and significantly correlated with industry skill intensity, while the share of import-only firms is negatively but not significantly correlated with industry skill intensity.

Importers exhibit a number of the same performance differences as exporters. As reported in Table 5 from Bernard et al. (2007b), importers are bigger, more productive, pay higher wages and are more skilland capital-intensive than non-importers. From a comparison of the first and second columns with the third

\footnotetext{
${ }^{11}$ The production of multiple products complicates the measurement of firm productivity when separate data on outputs, inputs and prices are not available at the firm-product level, as considered in Bernard et al. (2009c) and De Loecker (2011).
} 
column, the performance differences between firms that participate in international trade and those that do not are partly driven by firms that both import and export, which exhibit the largest performance differences from domestic firms. These findings suggest that trade liberalization is likely to benefit the largest, most productive, most skill- and capital-intensive firms within industries, not only through enhanced access to export markets, but also through improved availability of imported intermediate inputs.

While empirical studies of the impact of trade liberalization on productivity have typically focused on reductions in tariffs in output markets, more recent evidence suggests that reductions in tariffs on imported intermediate inputs may be a prominent source of productivity gains. Amiti \& Konings (2007) use manufacturing census data from Indonesia, which contains plant-level information on imported intermediate inputs, to construct separate measures of input and output tariffs. Following the trade liberalization that occurred in the 1990s, they find that reductions in input tariffs are associated with an increase in productivity of around 12 percent for firms that import their inputs, which is around twice as large as the effect for reductions in output tariffs.

Input tariffs may affect productivity through a number of potential channels, including learning about foreign technologies, expansion in the variety of intermediate inputs available for production, and access to higher-quality intermediate inputs. Following India's trade liberalization in the early 1990s, Goldberg et al. (2010) find that around two thirds of the growth in imports of intermediate inputs is accounted for by the extensive margin of newly imported products. In industries that experienced greater tariff reductions, there is a larger increase in total value, a greater reduction in prices and a larger expansion in variety of imported intermediate inputs. Consistent with the idea that the availability of new intermediate inputs expanded the technological possibilities of firms, industries that saw greater increases in the variety of imported intermediate inputs also experienced greater increases the range of products produced by Indian firms.

More generally, the presence of both importing and exporting within firms suggests the relevance of theories of the "fragmentation of production," such as Dixit \& Grossman (1982) and Grossman \& RossiHansberg (2008). In these models, firms can organize stages of production across national borders. Using input-output tables for 10 OECD and four emerging-market countries, Hummels et al. (2001) estimate that such vertical specialization accounts for around 20 percent of countries exports and grew by around 30 percent between 1970 and 1990. As shown in Yi (2003), when stages of production are spread across national boundaries in this way, changes in trade costs can have a magnified impact on trade flows, because they are incurred each time the good is traded back and forth between countries. ${ }^{12}$

\footnotetext{
${ }^{12}$ For a discussion of how global supply chains influenced the impact of the recent earthquake and tsunami in Japan, see Economist (2011).
} 


\section{$7 \quad$ Product Quality}

Even within narrowly-defined product categories, such as the $8,000+$ products of the ten-digit Harmonized System (HS) classification, there is tremendous variation in unit values across trade partners. A growing literature in international trade argues that this variation in prices reflects differences in product quality across trade partners, as in Schott (2004) and Hummels \& Klenow (2005). ${ }^{13}$ Furthermore, this variation in prices is strongly related to country endowments, with more capital and skill-abundant countries supplying varieties with higher prices within narrow product categories. According to this view, capital and skillabundant countries use their endowments to supply products of higher quality, and this higher product quality is reflected in a higher price.

Many papers use microdata to study the relationship between price variation and trade patterns at the firm level. For instance, Manova and Zhang (2011) use Chinese trade transactions data to highlight a number of systematic features of exports and imports by firm, product and destination that are consistent with heterogeneity in product quality. ${ }^{14}$ For example, across firms selling a given product, firms that charge higher export prices earn greater revenues in each destination, have bigger worldwide sales, and export to more markets. Across destinations within a firm-product, firms set higher prices in richer, larger, bilaterally more distant and overall less remote countries. Finally, firms that export pay a wider range of input prices and source inputs from more countries. Taken together these features of the data are consistent with a heterogeneous firm model where more successful exporters use higher-quality inputs to produce higher-quality goods and firms vary the quality of their products across destinations.

Using Colombian census of manufactures data, Kugler \& Verhoogen (2011) provide evidence of differences in product quality and highlight the relationship between firm export and import decisions. Within narrowly defined industries, larger firms charge more for their outputs and pay more for their inputs than smaller firms, and similar differences exist between exporters and non-exporters. This pattern of results is consistent with an extension of Melitz (2003), in which firms endogenously choose both input and output quality and there is a complementarity between the quality of inputs and outputs.

In Melitz (2003), the assumptions of constant elasticity of substitution (CES) preferences and monopolistic competition imply that firm productivity and product quality are isomorphic in the sense that they enter equilibrium firm revenue in exactly the same way. An empirical literature has sought to distinguish productivity and product quality by exploiting variation in prices across firms on the grounds that higher productivity implies lower prices whereas higher product quality can lead to higher prices, as explored in Baldwin \& Harrigan (2011) and Johnson (2010). One empirical challenge facing this literature is that firms supply horizontally differentiated varieties in Melitz (2003) and the specification of consumer preferences in

\footnotetext{
${ }^{13}$ For evidence on the role of product quality in explaining patterns of bilateral trade, see Hallak (2006).

${ }^{14}$ See also Bastos and Silva (2008) for evidence using Portuguese trade transactions data.
} 
which all varieties enter utility symmetrically implicitly imposes a choice of units in which to measure the quantity of each variety. There is no necessary relationship between this normalization and the units in which physical quantities of output are measured for each firm in the data. As a result, data on physical quantities of output cannot be directly compared across firms in the presence of horizontal product differentiation, which complicates the interpretation of variation in unit values across firms.

Using unit values to make inferences about the role of product quality in determining export patterns can be misleading because many factors other than quality affect prices. For instance, holding quality fixed, more efficient firms may find it optimal to charge lower prices for their products. Instead, recent papers obtain a proxy for product quality from demand residuals. Because consumers decide how much to purchase of each good by comparing quality-adjusted prices, two firms that charge the same price but have different market shares must sell varieties of different quality. In particular, firms that sell large quantities of physical output conditional on price are classified as high quality producers. Khandelwal (2011) applies this method to estimate quality for a broad sample of countries using aggregate trade data. He finds that markets characterized by relatively small scope for quality differentiation are associated with larger employment and output declines resulting from low-wage competition. Similarly, Hallak \& Schott (2011) estimate quality for a panel of 43 countries between 1989 and 2003. They find that export quality is correlated with the exporter's income per capita, but they also find that during this period quality levels are converging whereas income per capita is not. Finally, Gervais (2011) uses US Census data to estimate quality at the plant-level and decomposes cross-plant variation in price and export status into quality and efficiency margins. Prices are found to be increasing in quality and decreasing in efficiency, but, selection into exporting is driven mainly by quality.

\section{Intermediaries}

While in many models of international trade consumers purchase imports directly from foreign producers, the prevalence of firm importing has stimulated recent research on the role of intermediaries, such as wholesalers and retailers, in the process of international trade. Bernard et al. (2010c) examine the differences between wholesalers, retailers and other categories of U.S. trading firms. ${ }^{15}$ While wholesale firms comprise 35 percent of exporters and 42 percent of importers, they account for only 8 percent of export value and 15 percent of import value. Retailers are less prevalent and smaller than wholesalers, accounting for 9 percent of exporters and 13 percent of importers but only 1 percent of export and import value. In contrast, firms with operations in wholesale or retail and other sectors (typically large firms) comprise around only 5 percent of exporters and importers, but account for more than 60 percent of export value and more than 50 percent of import

\footnotetext{
${ }^{15} \mathrm{As}$ in most international trade datasets, firms that trade directly in LFTTD cannot be compared to those that trade indirectly via wholesalers or retailers, since the latter's sales or purchases within the U.S. are not observed.
} 
value. Therefore the vast majority of trade is undertaken by a relatively small number of large traders that vertically integrate Wholesaling/Retailing functions within firm boundaries. Using Italian trade transactions data, Bernard et al. (2010d) find that the share of exports mediated by wholesalers is positively correlated with proxies for country-specific fixed costs, including the World Bank's Doing Business measures of the number of documents for importing, cost of importing and time to import.

Using Chinese trade transactions data, Ahn et al. (2011) consider a different definition of intermediaries based on firms having the English-equivalent meaning of "importer," "exporter," and/or "trading" in their name. Such intermediary firms account for around $\$ 168$ billion of China's exports or around 22 percent of the total. The paper develops a model in which intermediaries are used by relatively small firms that do not find it profitable to incur the fixed costs of directly exporting to foreign markets by themselves. ${ }^{16}$ Consistent with intermediaries handling the products of other firms, they export relatively more products per destination market than other trading firms. In line with the idea that the fixed costs of direct exporting are more likely to be prohibitive in a small and remote foreign market, intermediaries account for larger export shares in smaller markets and markets with higher trade costs.

Blum et al. (2011) provide further indirect evidence on intermediation using matched importer-exporter transactions data for Chile and Colombia. Consistent with the concentration of U.S. trade discussed above, the distributions of bilateral exports and imports between Chile and Columbia are highly skewed across firms. More than half of exporters sell to only one importer, whereas the 99th percentile exporter sells to 19 importers. Similarly, more than half of importers deal with only one exporter, whereas the 99th percentile importers deals with 9 exporters. But, while one party to a transaction can be small and engage with few other traders, the other party to the transaction is typically large and deals with many other traders. This pattern of results is consistent with the idea that efficient trades involve large trade volumes, which can be achieved either by small importers matching with large exporters or small exporters matching with large importers. Motivated by these findings, the paper develops a theoretical model in which firms choose whether to access markets directly or indirectly via intermediaries. Since the direct exporting technology is characterized by increasing returns to scale, it is used by large exporters selling directly to many importers. In contrast, the intermediation technology is employed by large importers that spread the costs of intermediation over many small exporters.

More broadly, a key challenge in international trade is opening the black box of trade costs. Theories of heterogeneous firms and international trade posit the existence of fixed and variable trade cost parameters, but there is still little understanding of what these parameters capture. The literature on intermediaries in international trade takes some first steps towards understanding the chains of decisions involved in conducting goods from production to final consumption. Recent empirical research suggests that these trade and

\footnotetext{
${ }^{16}$ Other models of intermediation with similar patterns of selection of firms into intermediation and direct exporting include Akerman (2010) and Felbermayr \& Jung (2008).
} 
distribution networks may be important for a variety of issues in international trade, such as the border effect, exchange rate pass-through and the relationship between nominal and real exchange rates, as in Burstein et al. (2005) and $\mathrm{Li}$ et al. (2011). Other micro evidence on the potential importance of firm distribution networks comes from empirical findings of "Carry-Along Trade (CAT)" in Bernard et al. (2010e), where more than three quarters of the exported products and more than one quarter of export value from Belgian manufacturers are in goods that are not produced by firms. Recent theoretical research on search, networks and intermediation in international trade (e.g. Rauch \& Trinidade 2003, Petropoulou 2007, Antràs \& Costinot 2011) provides further guidance for future empirical work.

\section{Foreign Direct Investment}

While Melitz (2003) focuses on exports, Helpman et al. (2004) generalize the analysis to incorporate horizontal FDI, allowing firms to choose between incurring a fixed cost of exporting or a fixed cost of establishing an overseas affiliate. If the fixed costs of FDI are sufficiently high relative to the fixed costs of exporting, the most productive firms serve the foreign market through FDI; firms with a intermediate range of productivities export; firms with a lower range of productivities only serve the domestic market. With a Pareto productivity distribution, the importance of FDI relative to exporting as a mode for serving the foreign market is increasing in the dispersion of firm productivity. Consistent with this prediction, Helpman et al. (2004) show that the share of total foreign market sales accounted for by the sales of foreign affiliates is larger in industries with greater sales dispersion (as an empirical proxy for productivity dispersion).

Using Bureau of Economic Analysis (BEA) microdata on U.S. firms and their overseas affiliates, Yeaple (2009) provides further evidence in support of theories of heterogeneous firms and FDI. Consistent with firm selection, more productive U.S. firms own affiliates in a larger number of countries and these affiliates generate greater revenue on sales in their host countries. Consistent with country selection, as a country becomes more attractive to U.S. multinationals, it attracts progressively smaller and less productive firms. While the model accounts for many features of the data, there are others that are less well explained. The dispersion in the number of foreign countries entered is smaller than predicted by the model given the observed dispersion in U.S. market shares: large firms invest in too few foreign locations and small firms invest in too many, with the largest firms underrepresented among the least attractive locations.

Using Norwegian data, Irarrazabal et al. (2010) show that patterns of multinational activity by firm and destination market exhibit a number of similarities with the patterns of trade by firm and destination market in Eaton et al. (2011a). In particular, while total affiliate sales and the number of foreign affiliates are less sensitive to distance than exports, they both decline with distance. This gravity-equation relationship is inconsistent with a simple model of horizontal FDI, in which FDI should become more attractive as a mode 
for serving the foreign market as trade costs increase. ${ }^{17}$ To explain these findings, Irarrazabal et al. (2010) extend the model of firm heterogeneity and FDI of Helpman et al. (2004) to incorporate traded intermediate inputs and find empirical support for the extended model.

\section{Intra-Firm Trade}

While many models of FDI assume that overseas production is organized within the boundaries of the firm, this decision is itself endogenous. Furthermore, when FDI takes place, foreign affiliates may produce different stages of production (vertical FDI) instead of the same stage of production (horizontal FDI) as the parent firm. To the extent that stages of production are traded across national borders, whether overseas production is organized within the boundaries of the firm determines whether firm importing takes place between related parties or at arms length.

Related-party trade accounts for around one half of U.S. imports and exhibits a number of systematic patterns. ${ }^{18}$ In particular, intra-firm trade is concentrated in capital-intensive industries and between capitalabundant countries. To explain these features of the data, Antràs (2003) models a final goods producer who decides whether to outsource foreign production of an intermediate input to a standalone supplier or to engage in foreign direct investment (FDI) in which case the overseas production of the intermediate input is vertically integrated within the firm. The final goods producer and the intermediate input supplier make relationship-specific investments in capital and labor respectively. Contracts are incomplete because neither the quality of the intermediate input nor the amount of investments in capital and labor can be verified by a third party and contracts cannot be written on sales revenues. The only contractibles are therefore the allocation of residual rights on control and an ex ante transfer between the final goods supplier and intermediate input producer. Since the final goods producer's investment in capital is relatively more important in a capital-intensive industry, vertical integration is more likely in the capital-intensive industry, matching the empirical findings on U.S. imports. Furthermore, the model is also consistent with the empirical finding of a higher share of intra-firm trade in U.S. imports from capital-abundant countries, because there is greater intra-industry trade in the capital-intensive industry with these countries.

Antràs \& Helpman (2004) augment the analysis to incorporate firm heterogeneity. Since the fixed costs of producing abroad are lower when outsourcing to a foreign supplier than when using foreign direct investment, only the most productive firms can generate sufficient variable profits to offset the large fixed costs of vertical integration. As a result, the share of U.S. imports that are intra-firm is predicted to increase not only in the share of relationship-specific investments undertaken by the headquarters firm but also in the dispersion of

\footnotetext{
${ }^{17}$ In principle, the gravity equation relationship for affiliate sales and the number of affiliates can be reconciled with a model of horizontal FDI if there there are costs of operating foreign affiliates that increase with distance. See, for example, Keller \& Yeaple (2011) and Arkolakis et al. (2011b).

${ }^{18}$ U.S. import partners are defined as being "related" if either party owns, directly or indirectly, 6 percent or more of the other party.
} 
firm productivity. To examine these predictions, Nunn \& Trefler (2008) use U.S. data on related-party and arms-length trade by disaggregated HS 6-digit product and on capital and skill-intensity for more aggregated industries. Consistent with the predictions of the model, the share of intra-firm trade in U.S. imports is increasing in industry capital and skill-intensity (as proxies for the importance of headquarters investments), in the dispersion of U.S. exports within each 6-digit product (as a proxy for the dispersion of productivity), and in interactions between these two variables.

Antràs \& Helpman (2008) generalize the analysis to allow inputs to be partially contractible. In this framework, an improvement in foreign property rights has two offsetting effects on the share of intra-firm trade through the two productivity cutoffs which separate domestic production (low productivity), foreign outsourcing (intermediate productivity) and foreign vertical integration (high productivity). On the one hand, an improvement in foreign property rights reduces the productivity cutoff for outsourcing, as some inputs that were previously produced domestically are now outsourced abroad, which reduces the share of intra-firm trade. On the other hand, as foreign property rights improve, the intermediate input supplier's share of non-contractible inputs falls, which implies that the party whose investments require relatively more incentives is the headquarters firm. As a result, the productivity cutoff for vertical integration falls, as some inputs that were previously outsourced abroad are now vertically integrated abroad, which increases the share of intra-firm trade. For a range of parameter values, the second effect can dominate, which yields the surprising prediction that an improvement in foreign property rights can increase the extent of vertical integration. Consistent with this prediction, Nunn \& Trefler (2008) find that the share of intra-firm trade is positively related to interactions between capital and skill-intensity (as proxies for the importance of headquarters investments) and an empirical measure of the "rule of law" (as a proxy for the quality of foreign property rights)..$^{19}$

Additional empirical support for the above theoretical predictions is provided by Yeaple (2006), which uses Bureau of Economic Analysis (BEA) data on the value of imports by U.S. parent firms from their foreign affiliates as a measure of intra-firm trade. Consistent with the theoretical predictions of Antràs \& Helpman (2004), the share of intra-firm trade in U.S. imports is increasing in both industry capital-intensity and research and development (R\&D) intensity (as proxies for the importance of headquarters investments) and the dispersion of sales across establishments within industries (as a proxy for the dispersion of productivity). These estimated effects vary with U.S. trade partners' levels of development, with the largest and most precisely estimated coefficients found for the least-developed and newly-developing countries. ${ }^{20}$

\footnotetext{
${ }^{19}$ For more general evidence on the role of property rights in determining the pattern of trade, see Nunn (2007). Another dimension of institutions emphasized in the literature of heterogeneous firms and trade is credit constraints, as examined in Manova (2011).

${ }^{20}$ Corcos et al. (2010) and Defever \& Toubal (2010) examine the determinants of intra-firm trade using French trade transactions data. While Defever \& Toubal (2010) explore the implications of different assumptions about the relative magnitude of the fixed costs of outsourcing and vertical integration, Corcos et al. (2010) emphasize the distinction between the extensive and intensive margins.
} 
To further examine the determinants of intra-firm trade, Bernard et al. (2010b) use the trade-transactions and establishment-employment data in LFTTD to construct a new measure of products' "revealed contractibility," which is based on the idea that contracting is likely to be easier for products passing through intermediaries such as wholesalers. Intra-firm trade exhibits a non-linear relationship with these country and industry characteristics. On the one hand, higher quality property rights are associated with a higher probability of related-party trade taking place. On the other hand, conditional on positive related-party trade occurring, higher quality property rights are correlated with a lower share of related-party trade, which is consistent with the idea that higher quality property rights facilitate arms-length transactions.

\section{Labor Markets}

A key implication of the Melitz (2003) model is that firms are unevenly affected by trade liberalization: lowproductivity firms exit, intermediate-productivity domestic firms contract, and high-productivity exporting firms expand. In contrast, workers are symmetrically affected by trade liberalization, since workers are identical and labor markets are frictionless, so that all workers are employed for a common wage. These labor market implications sit awkwardly with the large empirical literature on the employer-size wage premium (see, for example, the survey by Oi \& Idson 1999) and empirical findings of wage differences between exporters and non-exporters even after controlling for firm size (see, in particular, Bernard \& Jensen 1995, 1997).

More recently, the theoretical literature on heterogeneous firms and trade has highlighted two sets of reasons why wages can vary with revenue across firms. One line of research assumes competitive labor markets, so that all workers with the same characteristics are paid the same wage, but wages vary across firms as a result of differences in workforce composition (see for example Bustos 2007, Verhoogen 2008 and Yeaple 2005). Another line of research introduces labor market frictions, so that workers with the same characteristics can be paid different wages by different firms. One source of labor market imperfections is search and matching frictions, where bargaining over the surplus from production can potentially induce wages to vary with revenue across firms (see for example Davidson et al. 2008, Cosar et al. 2011, and Helpman et al. 2010). Another source of labor market imperfections is efficiency or fair wages, where the wage that induces effort or is perceived to be fair varies with revenue across firms (see for example Amiti \& Davis 2011, Davis \& Harrigan 2011, and Egger \& Kreickemeier 2009). ${ }^{21}$

This class of theoretical models highlights a new mechanism for trade to affect wage inequality based on wage variation across firms and the selection of firms into international markets. Helpman et al. (2011) provide evidence on the quantitative importance of this new mechanism for understanding the relationship between wage inequality and trade using Brazilian employer-employee data. Consistent with the class of

\footnotetext{
${ }^{21}$ In the presence of labor market frictions, trade may also affect income inequality through changes in unemployment, as in Felbermayr et al. 2011 and Helpman and Itskhoki (2010).
} 
theoretical models discussed above, the rise in overall wage inequality is driven by a rise in wage inequality within sector-occupations for workers with similar observed occupations; this rise in wage inequality within sector-occupations occurs between rather than within-firms; and the change in between-firm wage dispersion is systematically related to firm trade participation. To the extent that existing empirical studies inspired by neoclassical trade theory focus on changes in relative wages between different sectors and types of workers, they abstract from an important channel through which trade liberalization can affect wage inequality.

A number of recent empirical studies have used matched employer-employee data to try to determine whether wage differences between exporters and non-exporters (as found by Bernard \& Jensen 1995, 1997) are the result of differences in the composition of workers across firms or wage premia for workers with the same characteristics. Following Abowd et al. (1999, 2001), this literature typically estimates worker and firm fixed effects under the strong identifying assumptions that switches of workers between firms are random conditional on the covariates and that each worker's wage is a log linear function of their ability and does not depend directly on the ability of their co-workers. Empirical studies within this literature generally find contributions from both differences in workforce composition and wage premia, with the relative magnitude of these contributions varying across studies. Using Mexican data, Frías et al. (2009) find that approximately two-thirds of the higher level of wages in larger, more productive plants is explained by higher levels of wage premia and that nearly all of the differential changes in wages within industries as a result of the shock of the peso devaluation are explained by changes in wage premia. Using German data, Schank et al. (2007) find that wage differences between exporters and non-exporters become smaller but do not completely vanish once observable and unobservable characteristics of the employees and of the workplace are controlled for. ${ }^{22}$

Amiti \& Davis (2011) provide theory and evidence on the separate impacts of input and output tariffs on firm wages. An augmented version of the Melitz (2003) model to incorporate firm importing predicts that a fall in output tariffs lowers wages at import-competing firms, but boosts wages at exporting firms. Similarly, a fall in input tariffs raises wages at import-using firms relative to those at firms that only source inputs locally. Using Indonesian firm-level census of manufactures data, which reports firm-level measures of intermediate input use that are used to construct input tariffs, they find strong empirical support for both predictions. ${ }^{23}$

\section{Firm Export Market Dynamics}

Much of the theoretical and empirical literature on heterogeneous firms and trade focuses on the cross-section distribution of trade across firms, products and countries. More recent research has begun to explore the

\footnotetext{
${ }^{22}$ For evidence using Brazilian and Swedish employer-employee data, see Krishna et al. (2010) and Davidson et al. (2010) respectively.

${ }^{23}$ For evidence on the relationship between the firm skill premium and input and output tariffs, see Amiti and Cameron (2011).
} 
dynamics of firm's decisions to enter export markets and its implications for the impact of trade liberalization.

Using transactions-level customs data for Colombia, Eaton et al. (2008) examines the dynamics of firmdestination exports over the period 1996-2005. In a typical year, nearly one half of all Colombian exporters were not exporters in the previous year. These new exporters are small as a share of total exports and most do not continue exporting in the following year. Total exports are instead dominated by a small number of large and stable exporters. Nonetheless, out of each cohort of new exporters, a fraction of firms go on to rapidly expand exports, and over the period of less than a decade, these successful new exporters account for almost half of total export growth. Firms typically begin exporting in a single foreign market and, if they survive, gradually expand into additional destinations. The geographic pattern of their expansion paths, and their likelihood of survival as exporters, depend on their initial destination market.

One line of research has sought to explain these export dynamics in terms of learning, as in Eaton et al. (2011c), Akhmetova (2011), and Albornoz et al. (2011). According to this view, firms update their priors about profitability in export markets based upon their initial sales, and hence either exit or expand their penetration of export markets over time. In Albornoz et al. (2011), export market profitability is uncertain and correlated across export markets. As a result, a firm may enter an export market even if the expected profits from entering that market alone are negative, because of the option value of expanding to additional export markets if successful. An implication of this framework is that firm export market growth should be particularly rapid in the first year of exporting, which receives empirical support in Argentinian trade transactions data. ${ }^{24}$

Another line of research tries to explain these export dynamics through stochastically shocks to productivity, as in Arkolakis (2011) and Ruhl and Willis (2011). As productivity evolves over time, firms decide whether to enter or exit individual export markets and whether or not to continue production. In Arkolakis (2011), these stochastic shocks to productivity are combined with a model of endogenous market penetration. A firm enters a market if it is profitable to incur the marginal cost to reach the first consumer and pays an increasing market penetration cost to reach additional consumers. The model is calibrated using data on the cross-section of firms and their sales across markets as well as the rate of incumbent firm exit. The calibrated model is shown to be quantitatively successful in predicting firm exit, growth, and the resulting firm-size distribution in the US manufacturing data.

Bernard et al. (2009b) use transaction level data to compare the role of the extensive and intensive margins in accounting for cross-section and time-series patterns of trade. The extensive margins of the number of firms and products drive the majority of the variation in trade flows across countries. In contrast, year-on-year changes in trade are driven by the intensive margin of trade within continuing firm-product-

\footnotetext{
${ }^{24}$ In the presence of learning and imperfect contract enforcement, Araujo et al. (2011) argue that institutions may affect export dynamics. Other things equal, exporters have higher initial exports and remain as exporters for longer in countries with better contracting institutions. However, conditional on survival, the growth rate of a firm's exports to a country decreases with the quality of the country's institutions.
} 
country trade relationships. One reason for the relative small contributions of extensive margins over short time intervals is that entering and exiting exporters, as well as recently added and about-to-be-dropped firmproduct-country trade relationships, are on average relatively small compared to continuing firm-productcountry trade relationships. Conversely, conditional on survival, entering exporters and recently added firm-product-country trade relationships grow more rapidly than incumbent exporters and continuing firmproduct-country trade relationships. Analysis of the Asian crisis in the late 1990s confirms these time-series results: while there are substantial changes in the extensive margin of the number of exporters, the majority of the change in the dollar value of trade around the Asian crisis is driven by the intensive margin. Notably, the extensive and intensive margins behave differently for arms-length and related-party trade, suggesting that the global production networks of large multinational corporations play a role in influencing the response of the macroeconomy to shocks.

\section{Conclusion}

Empirical findings from microdata on plants and firms proposed a number of challenges to traditional theories of international trade and stimulated the development of new models of heterogeneous firms and trade. These new theories explain empirical findings that only some firms export, exporters are larger and more productive than non-exporters, and trade liberalization raises average productivity through reallocations of resources across firms within industries.

These new theories highlight additional mechanisms through which the aggregate economy is affected by the opening of trade and have stimulated further empirical research exploring these mechanisms. Aggregate economic relationships such as the gravity equation are largely driven by the extensive margins of firms and products rather than the intensive margin of average exports per firm-product. Reductions in trade costs induce endogenous changes in internal firm organization as firms adjust their range products, their decisions about whether to serve foreign markets through trade or overseas production, and their choices about whether to organize foreign production within or beyond the boundaries of the firm. To the extent that wages vary with firm revenue and only some firms export, firm heterogeneity provides a new mechanism for trade to affect wage inequality.

While early research concentrated on firm exporting using plant or firm-level data, the availability of customs data on individual trade transactions has enhanced our ability to look inside the black box of the firm and led to an explosion of research across a broad range of areas. These include multi-product firms, intra-firm trade, intermediation, and the dynamics of firm entry into export markets. There remain many fundamental issues ahead, such as the microfoundations of trade costs, further exploration of the boundaries of the firm, and further consideration of the relationship between findings from disaggregated data and the economy's aggregate response to trade. 


\section{References}

Abowd JM, Kramarz F, Margolis DN. 1999. High Wage Workers and High Wage Firms. Econometrica. 67(2): 251-333.

Abowd JM, Creecy RH, Kramarz F. 2002. Computing Person and Firm Effects Using Linked Longitudinal Employer-Employee Data. (Cornell University, Unpublished).

Ahn JB, Khandelwal A, Wei SJ. 2011. The Role of Intermediaries in Facilitating Trade. Journal of International Economics. Forthcoming.

Akerman A. 2010. A Theory on the Role of Wholesalers in International Trade Based on Economies of Scope. (Stockholm University, Unpublished).

Akhmetova Z. 2011. Firm Experimentation in New Markets. (University of New South Wales, Unpublished).

Albornoz F, Calvo-Pardo H, Corcos G, Ornelas E. 2011. Sequential Exporting. (London School of Economics, Unpublished).

Allanson P, Montagna C. 2005. Multi-product Firms and Market Structure: An Explorative Application to the Product Lifecycle. International Journal of Industrial Organization. 23: 587-97.

Alvarez R, López RA. 2005. Exporting and Performance: Evidence from Chilean Plants. Canadian Journal of Economics. 38(4): 1384-400.

Amiti M, Cameron L. 2011. Trade Liberalization and the Wage Skill Premium: Evidence from Indonesia. New York Federal Reserve Bank, mimeograph.

Amiti M, Davis DR. 2011. Trade, Firms, and Wages: Theory and Evidence. Review of Economic Studies. Forthcoming.

Amiti M, Konings J. 2007. Trade Liberalization, Intermediate Inputs, and Productivity. American Economic Review. 97(5): 1611-38.

Antràs P. 2003. Firms, Contracts, and Trade Structure. Quarterly Journal of Economics. 118(4): 1375-1418. 
Antràs P, Helpman E. 2004. Global Sourcing. Journal of Political Economy. 112(3): 552-80.

Antràs P, Helpman E. 2008. Contractual Frictions and Global Sourcing. In The Organization of Firms in a Global Economy, ed. E Helpman, D Marin, T Verdier. Cambridge MA: Harvard University Press.

Antràs P, Costinot A. 2011. Intermediated Trade. Quarterly Journal of Economics. Forthcoming.

Araujo L, Mion G, Ornelas E. (2011) Institutions and Export Dynamics (London School of Economics, Unpublished).

Arkolakis C. 2010. Market Penetration Costs and the New Consumers Margin in International Trade. Journal of Political Economy. 118(6): 1151-99.

Arkolakis C. 2011. A Unified Theory of Firm Selection and Growth. (Yale University, Unpublished).

Arkolakis C, Klenow P, Demidova S, Rodriguez-Clare A. 2008. Endogenous Variety and The Gains from Trade. American Economic Review. Papers and Proceedings. 98(2): 444-50.

Arkolakis C, Costinot A, Rodriguez-Clare A. 2011a. New Trade Models, Same Old Gains? American Economic Review. Forthcoming.

Arkolakis C, Ramondo N, Rodriguez-Clare A, Yeaple S. 2011b. Proximity Versus Comparative Advantage: A Quantitative Theory of Trade and Multinational Production. (Yale University, Unpublished).

Arkolakis C, Muendler M. 2010. The Extensive Margin of Exporting Products: A Firm-level Analysis. NBER Working Paper. 16641.

Atkeson A, Burstein A. 2010. Innovation, Firm dynamics, and International Trade. Journal of Political Economy. 118(3): 433-84.

Aw BY, Roberts MJ, Xu DY. 2011. R\&D Investment, Exporting, and Productivity Dynamics. American Economic Review. 101 (4): 1312-44.

Axtell RL. 2001. Zipf Distribution of US Firm Sizes. Science. 293:1818-20.

Baldwin J, Gu W. 2009. The Impact of Trade on Plant Scale, Production-Run Length and Diversification. In Producer Dynamics: New Evidence from Micro Data, ed. T Dunne, JB Jensen, MJ Roberts. Chicago: University of Chicago Press.

Baldwin R, Harrigan J. 2011. Zeros, Quality, and Space: Trade Theory and Trade Evidence. American Economic Journal: Microeconomics. 3: 60-88.

Bastos P., Silva J. 2008. The Quality of a Firm's Exports: Where you Export to Matters. GEP Research Paper 2008/18. University of Nottingham.

Bernard AB, Jensen JB. 1995. Exporters, Jobs, and Wages in US Manufacturing: 1976-87. Brookings Papers on Economic Activity: Microeconomics. 67-112.

Bernard AB, Jensen JB. 1997. Exporters, Skill Upgrading and the Wage Gap. Journal of International Economics. 42: 3-31. 
Bernard AB, Jensen JB. 1999. Exceptional Exporter Performance: Cause, Effect, or Both? Journal of International Economics. 47(1): 1-25.

Bernard AB, Eaton J, Jensen JB, Kortum SS. 2003. Plants and Productivity in International Trade. American Economic Review. 93(4): 1268-90.

Bernard AB, Jensen JB. 2004. Why Some Firms Export. Review of Economics and Statistics. 86(2): 561-69.

Bernard AB, Jensen JB, Schott PK. 2006a. Trade Costs, Firms and Productivity. Journal of Monetary Economics. 53(5).

Bernard AB, Jensen JB and Schott PK. 2006b. Survival of the Best Fit: Exposure to Low-Wage Countries and the (Uneven) Growth of US Manufacturing Plants. Journal of International Economics. 68: 219-37.

Bernard AB, Redding SJ, Schott PK. 2007a. Comparative Advantage and Heterogeneous Firms. Review of Economic Studies, 74(1): 31-66.

Bernard AB, Jensen JB, Redding SJ, Schott PK. 2007b. Firms in International Trade. Journal of Economic Perspectives. 21(3): 105-30.

Bernard AB, Jensen JB, Schott PK. 2009a. Importers, Exporters and Multinationals: A Portrait of Firms in the U.S. that Trade Goods. In Producer Dynamics: New Evidence from Micro Data, ed. T Dunne, JB Jensen, MJ Roberts. Chicago: University of Chicago Press.

Bernard AB, Jensen JB, Redding SJ, Schott PK. 2009b. The Margins of U.S. Trade. American Economic Review. Papers and Proceedings. 99(2): 487-93.

Bernard AB, Redding SJ, Schott PK. 2009c. Products and Productivity. Scandinavian Journal of Economics. 111(4): 681-709.

Bernard AB, Redding SJ, Schott PK. 2010a. Multi-product Firms and Product Switching. American Economic Review. 100(1): 70-97.

Bernard AB, Jensen JB, Redding SJ, Schott PK. 2010b. Intra-firm Trade and Product Contractibility. American Economic Review. Papers and Proceedings. 100(2): 444-48.

Bernard AB, Jensen JB, Redding SJ, Schott PK. 2010c. Wholesalers and Retailers in U.S. Trade. American Economic Review. Papers and Proceedings. 100(2): 408-13.

Bernard AB, Grazzi M, Tomasi C. 2010d. Intermediaries in International Trade: Direct versus Indirect Modes of Export. National Bank of Belgium Working Paper. 199.

Bernard AB, Van Beveren I, Vandenbussche H. 2010e. Multi-Product Exporters, Carry-Along Trade and the Margins of Trade. National Bank of Belgium Working Paper. 203.

Bernard AB, Redding SJ, Schott PK. 2011. Multi-product Firms and Trade Liberalization. Quarterly Journal of Economics, forthcoming.

Blum BS, Claroz S, Horstmann IJ. 2011. Intermediation and the Nature of Trade Costs: Theory and Evidence. (University of Toronto, Unpublished). 
Broda C, Weinstein D. 2006. Globalization and the Gains from Variety. Quarterly Journal of Economics, 121(2): 541-85.

Burstein A, Eichenbaum M, Rebelo S. 2005. Large Devaluations and the Real Exchange Rate. Journal of Political Economy. 113(4): 742-784.

Burstein A, Vogel J. 2010. Globalization, Technology, and the Skill Premium: A Quantitative Analysis. (Columbia University, Unpublished).

Bustos P. 2007. The Impact of Trade Liberalization on Skill Upgrading: Evidence from Argentina. (CREI, Unpublished).

Bustos P. 2011. Trade Liberalization, Exports and Technology Upgrading: Evidence on the impact of MERCOSUR on Argentinian Firms. American Economic Review. 101(1): 304-40.

Caliendo L, Rossi-Hansberg E. 2011. The Impact of Trade on Organization and Productivity. (Princeton University, Unpublished).

Chaney T. 2005. Liquidity Constrained Exporters. (University of Chicago, Unpublished).

Chaney T. 2008. Distorted Gravity: The Intensive and Extensive Margins of International Trade. American Economic Review. 98(4): 1707-21.

Cherkashin I, Demidova S, Kee HL, Krishna K. 2010. Firm Heterogeneity and Costly Trade: A New Estimation Strategy and Policy Experiments. (Penn State University, Unpublished).

Clerides S, Lach S, Tybout J. 1998. Is Learning by Exporting Important? Micro-dynamic Evidence from Columbia, Mexico and Morocco. Quarterly Journal of Economics. 113: 903-47.

Constantini J, Melitz MJ. 2008. The Dynamics of Firm-Level Adjustment to Trade Liberalization. In The Organization of Firms in a Global Economy, ed. E Helpman, D Marin, T Verdier, 4:107-41. Cambridge MA: Harvard University Press. 356 pp.

Corcos G, Del Gatto M, Mion G and Ottaviano GIP. 2010. Productivity and Firm Selection: Quantifying the "New" Gains from Trade. (London School of Economics, Unpublished).

Coçsar AK, Guner N, Tybout J. 2011. Firm Dynamics, Job Turnover, and Wage Distributions in an Open Economy. (Penn State University, Unpublished).

Cuñat A, Melitz MJ. 2011. Volatility, Labor Market Flexibility and Comparative Advantage. Journal of the European Economics Association. Forthcoming.

Das M, Roberts MJ, Tybout J. 2007. Market Entry Costs, Producer Heterogeneity and Export Dynamics. Econometrica. 75(3): 837-73.

Davidson C, Matusz S, Shevchenko A. 2008. Globalization and Firm-level Adjustment with Imperfect Labor Markets. Journal of International Economics. 75: 295-309.

Davidson C, Heyman F, Matusz S, Sjoholm F, Zhu S. 2010. Globalization and Imperfect Labor Market Sorting. (Michigan State University, Unpublished). 
Davis DR, Harrigan J. 2011. Good Jobs, Bad Jobs, and Trade Liberalization. Journal of International Economics. Forthcoming.

De Loecker, J. 2007. Do Exports Generate Higher Productivity? Evidence from Slovenia. Journal of International Economics. 73: 69-98.

De Loecker J. 2011. Product Differentiation, Multi-Product Firms and Estimating the Impact of Trade Liberalization on Productivity. Econometrica. Forthcoming.

De Loecker J, Warzynski F. 2011. Markups and Firm-level Export Status. (Princeton University, Unpublished).

Defever F, Toubal F. 2010. Productivity and the Sourcing Modes of Multinational Firms: Evidence from French Firm-Level Data. (University of Nottingham, Unpublished).

Dhingra S. 2010. Trading Away Wide Brands for Cheap Brands. (London School of Economics, Unpublished).

Dixit A, Grossman GM. 1982. Trade and Protection with Multi-Stage Production. Review of Economic Studies. 49(4): 583-94.

Eaton J, Kortum SS. 2002. Technology, Geography, and Trade. Econometrica. 70(5): 1741-79.

Eaton J, Kortum SS, Kramarz F. 2004. Dissecting Trade: Firms, Industries, and Export Destinations. American Economic Review. Papers and Proceedings. 94: 150-54.

Eaton J, Eslava M, Kugler M, Tybout JR. 2008. Export Dynamics in Colombia: Firm-level Evidence. In The Organization of Firms in a Global Economy, ed. E Helpman, D Marin, T Verdier, 8:231-72. Cambridge MA: Harvard University Press. 356 pp.

Eaton J, Kortum SS, Kramarz F. 2011a. An Anatomy of International Trade: Evidence from French Firms. Econometrica, forthcoming.

Eaton J, Kortum SS, Sotelo S. 2011b. International Trade: Linking Micro and Macro. (University of Chicago, Unpublished).

Eaton J, Eslava M, Krizan CJ, Kugler M, Tybout J. 2011c. A Search and Learning Model of Export Dynamics. (Penn State University, Unpublished).

Eckel C, Neary JP. 2010. Multi-product Firms and Flexible Manufacturing in the Global Economy. Review of Economic Studies. 77(1): 188-217.

Economist. 2011. Broken links: The disruption to manufacturers worldwide from Japan's disasters will force a rethink of how they manage production. 31 March 2011. http://www.economist.com/node/18486015.

Egger H, Kreickemeier U. 2009. Firm Heterogeneity and the Labour Market Effects of Trade Liberalization. International Economic Review. 50(1): 187-216.

Ethier WJ. 1982. National and International Returns to Scale in the Modem Theory of International Trade. American Economic Review. 72: 389-405. 
Feenstra R, Ma H. 2008. Optimal Choice of Product Scope for Multiproduct Firms. In The Organization of Firms in a Global Economy, ed. E Helpman, D Marin, T Verdier. Cambridge MA: Harvard University Press.

Felbermayr G, Jung B. 2008. Trade Intermediaries, Incomplete Contracts, and the Choice of Export Modes. (University of Hohenheim, Unpublished).

Felbermayr G, Prat J, Schmerer HJ. 2011. Globalization and Labor Market Outcomes: Wage Bargaining, Search Frictions, and Firm Heterogeneity. Journal of Economic Theory. 146(1): 39-73.

Frías J, Kaplan D, Verhoogen E. 2009. Exports and Wage Premia: Evidence from Mexican EmployerEmployee Data. (Unpublished, Columbia University).

Gervais, A. 2011. Product Quality, Firm Heterogeneity and International Trade. (Unpublished, University of Notre Dame).

Goldberg PK, Khandelwal AK, Pavcnik N, Topalova P. 2010. Imported Intermediate Inputs and Domestic Product Growth: Evidence from India. Quarterly Journal of Economics. 125(4): 1727-67.

Grossman GM, Rossi-Hansberg E. 2008. Trading Tasks: A Simple Theory of Offshoring. American Economic Review. 98(5): 1978-97.

Hallak JC. 2006. Product Quality and the Direction of Trade. Journal of International Economics. 68(1): $238-65$.

Hallak JC, Schott PK. 2011. Estimating Cross-Country Differences in Product Quality. Quarterly Journal of Economics, 126(1): 417-74.

Harrigan J, Resheff A. 2011. Skill-biased Heterogeneous Firms: Trade Liberalization and the Skill Premium Redux. (University of Virginia, Unpublished).

Helpman E. 1981. International Trade in the Presence of Product Differentiation, Economies of Scale, and Monopolistic Competition: A Chamberlin-Heckscher-Ohlin model. Journal of International Economics. 11: $305-40$.

Helpman E. 1999. The Structure of Foreign Trade. Journal of Economic Perspectives. 13(2): 121-44.

Helpman E. 2006. Trade, FDI and the Organization of Firms. Journal of Economic Literature. XLIV: $589-630$.

Helpman E, Itskhoki O. 2010. Labor Market Rigidities, Trade and Unemployment. Review of Economic Studies. 77(3): 1100-37.

Helpman E, Itskhoki O, Redding S. 2010. Inequality and Unemployment in a Global Economy. Econometrica. $78(4): 1239-83$.

Helpman E, Itskhoki O, Muendler M, Redding S. 2011. Wage Inequality and Trade: Evidence from Brazil. (Princeton University, Unpublished).

Helpman E, P Krugman. 1985. Market Structure and Foreign Trade. Cambridge MA: MIT Press. 
Helpman E, Melitz MJ, Yeaple SR. 2004. Export Versus FDI with Heterogeneous Firms. American Economic Review. 94(1): 300-16.

Helpman E, Melitz MJ, Rubinstein Y. 2008. Estimating Trade Flows: Trading Partners and Trading Volumes. Quarterly Journal of Economics. 123(2): 441-87.

Holmes TJ, Stevens JJ. 2010. Exports, Borders, Distance, and Plant Size. NBER Working Paper. 16046.

Hsieh C, Ossa R. 2010. A Global View of Productivity Growth in China and India. (University of Chicago, Unpublished).

Hummels D, Klenow P. 2005. The Variety and Quality of a Nation's Exports. American Economic Review. 95: $704-23$.

Hummels D, Ishii J, Yi K. 2001. The Nature and Growth of Vertical Specialization in World Trade. Journal of International Economics. 54: 75-96.

Irarrazabal A, Moxnes A, Opromolla LD. 2010. The Margins of Multinational Production and the Role of Intrafirm Trade. (Dartmouth College, Unpublished).

Javorcik B, Neary JP, Eckel C, Iacovone L. 2010. Multi-Product Firms at Home and Away: Cost- Versus Quality-Based Competence. (University of Oxford, Unpublished).

Johnson R. 2010. Trade and Prices with Heterogeneous Firms. (Dartmouth College, Unpublished).

Keller W, Yeaple S. 2011. Gravity in the Weightless Economy. (Penn State University, Unpublished).

Khandelwal, A. 2011. The Long and Short (of) Quality Ladders. Review of Economic Studies. 77(4): $1450-76$.

Krishna P, Poole JP, Senses MZ. 2010. Trade Liberalization, Firm Heterogeneity and Wages: New Evidence from Matched Employer-Employee Data. (Johns Hopkins University, Unpublished).

Krugman P. 1980. Scale Economies, Product Differentiation, and the Pattern of Trade. American Economic Review. 70: 950-59.

Kugler M, Verhoogen E. 2011. Prices, Plant Size, and Product Quality. Review of Economic Studies. Forthcoming.

Li N, Gopinath G, Gourinchas P, Hsieh C. 2011. International Prices, Costs and Markup Differences. American Economic Review. Forthcoming.

Lileeva A, Trefler D. 2010. Improved Access to Foreign Markets Raises Plant-Level Productivity ... for Some Plants. Quarterly Journal of Economics. 125(3): 1051-99.

Manova K. 2011. Credit Constraints, Heterogeneous Firms, and International Trade. (Stanford University, Unpublished).

Manova K, Zhang Z. 2011. Export Prices across Firms and Destinations. Quarterly Journal of Economics. Forthcoming. 
Mayer T, Melitz MJ, Ottaviano G. 2011. Market Size, Competition, and the Product Mix of Exporters. NBER Working Paper. 16959.

Mayer T, Ottaviano GIP. 2007. The Happy Few: New Facts on the Internationalisation of European Firms. Bruegel - CEPR EFIM Report. Bruegel Blueprint Series.

Melitz MJ. 2003. The Impact of Trade on Intra-Industry Reallocations and Aggregate Industry Productivity. Econometrica. 71: 1695-725.

Melitz, MJ, Ottaviano GIP. 2008. Market Size, Trade, and Productivity. Review of Economic Studies. 75 : 295-316.

Nocke V, Yeaple SR. 2006. Globalization and Endogenous Firm Scope. NBER Working Paper. 12322.

Nunn N. 2007. Relationship-Specificity, Incomplete Contracts and the Pattern of Trade. Quarterly Journal of Economics. 122(2): 569-600.

Nunn N, Trefler D. 2008. The Boundaries of the Multinational Firm: An Empirical Analysis. In The Organization of Firms in a Global Economy, ed. E Helpman, D Marin, T Verdier, 55-83. Cambridge MA: Harvard University Press.

Oi WY, Idson TL. 1999. Firm Size and Wages. In Handbook of Labor Economics, ed. O Ashenfelter, D Card, 3, 33, 2165-214, Amsterdam: Elsevier.

Ottaviano GIP, Thisse J. 1999. Monopolistic Competition, Multiproduct Firms and Optimum Product Diversity. CEPR Discussion Paper. 2151.

Pavcnik N. 2002. Trade Liberalization, Exit, and Productivity Improvement: Evidence from Chilean Plants. Review of Economic Studies. 69(1): 245-76.

Petropoulou D. 2007. Information Costs, Networks and Intermediation in International Trade. Discussion Paper. 370. Department of Economics. University of Oxford.

Rauch J, Trindade V. 2003. Information, International Substitutability, and Globalization. American Economic Review. 93: 775-91.

Redding SJ. 2011. Theories of Heterogeneous Firms and Trade. Annual Review of Economics. Forthcoming.

Roberts MJ, Tybout J. 1997. The Decision to Export in Colombia: An Empirical Model of Entry with Sunk Costs. American Economic Review. 87(4): 545-64.

Ruhl KJ, Willis JL. 2008. New Exporter Dynamics. (NYU Stern School of Business, Unpublished).

Santos Silva JMC, Tenreyro S. 2006. The Log of Gravity. Review of Economics and Statistics. 88(4): 641-58.

Schank T, Schanbel C, Wagner J. 2007. Do Exporters Really Pay Higher Wages? First Evidence from German Linked Employer-Employee Data. Journal of International Economics. 72: 52-74.

Schott PK. 2004. Across-Product versus Within-Product Specialization in International Trade. Quarterly Journal of Economics. 119(2): 647-78. 
Trefler D. 2004. The Long and Short of the Canada-U.S. Free Trade Agreement. American Economic Review. 94: 870-95.

Tybout J. 2003. Plant- and Firm-Level Evidence on the 'New' Trade Theories. In Handbook of International Trade, ed. EK Choi and J Harrigan, 13. Oxford: Basil Blackwell.

Van Biesebroeck J. 2005. Exporting Raises Productivity in Sub-Saharan African Manufacturing Firms. Journal of International Economics. 67(2): 373-91.

Verhoogen E. 2008. Trade, Quality Upgrading and Wage Inequality in the Mexican Manufacturing Sector. Quarterly Journal of Economics. 123(2): 489-530.

World Trade Organization. 2008. World Trade Report: Trade in a Globalizing World. Geneva: World Trade Organization.

Yeaple SR. 2005. A Simple Model of Firm Heterogeneity, International Trade, and Wages. Journal of International Economics. 65: 1-20.

Yeaple SR. 2006. Offshoring, Foreign Direct Investment, and the Structure of U.S. Trade. Journal of the European Economic Association. 4: 602-11.

Yeaple SR. 2009. Firm Heterogeneity and the Structure of U.S. Multinational Activity: An Empirical Analysis. Journal of International Economics. 78(2): 206-15.

Yi K. 2003. Can Vertical Specialization Explain the Growth of World Trade? Journal of Political Economy. 111(1): 52-102. 
Table 1: Exporting by U.S. Manufacturing Firms, 2002

\begin{tabular}{|c|c|c|c|c|}
\hline \multicolumn{2}{|c|}{ NAICS Industry } & \multirow{2}{*}{$\frac{\text { Percent of Firms }}{6.8}$} & \multirow{2}{*}{$\begin{array}{c}\begin{array}{c}\text { Percent of Firms } \\
\text { that Export }\end{array} \\
11.6\end{array}$} & \multirow{2}{*}{$\begin{array}{c}\text { Mean Exports as a } \\
\text { Percent of Total } \\
\text { Shipments }\end{array}$} \\
\hline 311 & Food Manufacturing & & & \\
\hline 312 & Beverage and Tobacco Product & 0.7 & 22.9 & 7.4 \\
\hline 313 & Textile Mills & 1.0 & 25.1 & 12.5 \\
\hline 314 & Textile Product Mills & 1.9 & 12.2 & 11.7 \\
\hline 315 & Apparel Manufacturing & 3.2 & 7.7 & 13.5 \\
\hline 316 & Leather and Allied Product & 0.4 & 24.4 & 13.4 \\
\hline 321 & Wood Product Manufacturing & 5.5 & 8.5 & 18.5 \\
\hline 322 & Paper Manufacturing & 1.4 & 23.8 & 9.0 \\
\hline 323 & Printing and Related Support & 11.9 & 5.5 & 14.4 \\
\hline 324 & Petroleum and Coal Products & 0.4 & 17.8 & 11.5 \\
\hline 325 & Chemical Manufacturing & 3.1 & 36.1 & 14.3 \\
\hline 326 & Plastics and Rubber Products & 4.4 & 28.1 & 10.3 \\
\hline 327 & Nonmetallic Mineral Product & 4.0 & 9.5 & 12.1 \\
\hline 331 & Primary Metal Manufacturing & 1.5 & 30.2 & 10.4 \\
\hline 332 & Fabricated Metal Product & 19.9 & 14.3 & 11.6 \\
\hline 333 & Machinery Manufacturing & 9.0 & 33.0 & 15.5 \\
\hline 334 & Computer and Electronic Product & 4.5 & 38.3 & 21.3 \\
\hline 335 & Electrical Equipment, Appliance, & 1.7 & 37.7 & 12.9 \\
\hline 336 & Transportation Equipment & 3.4 & 28.0 & 13.0 \\
\hline 337 & Furniture and Related Product & 6.4 & 6.5 & 10.1 \\
\hline 339 & Miscellaneous Manufacturing & 9.1 & 1.6 & 14.9 \\
\hline \multicolumn{2}{|c|}{ Aggregate Manufacturing } & 100.0 & 17.6 & 14.1 \\
\hline
\end{tabular}

Source: Bernard et al. (2007).

Notes: Data are from the 2002 U.S. Census of Manufactures. Column 2 summarizes the distribution of manufacturing firms across three-digit NAICS manufacturing industries. Column 3 reports the share of firms in each industry that export. The final column reports mean exports as a percent of total shipments across all firms that export in the noted industry. 
Table 2: Exporter Premia in U.S. Manufacturing

\begin{tabular}{lccc}
\hline \hline & $(1)$ & $(2)$ & $(3)$ \\
\hline Log Employment & 1.19 & 0.97 & $\cdot$ \\
Log Shipments & 1.48 & 1.08 & 0.08 \\
Log Value Added per Worker & 0.26 & 0.11 & 0.10 \\
Log TFP & 0.02 & 0.03 & 0.05 \\
Log Wage & 0.17 & 0.06 & 0.06 \\
Log Capital per Worker & 0.32 & 0.12 & 0.04 \\
Log Skill per Worker & 0.19 & 0.11 & 0.19 \\
\hline \multicolumn{2}{c}{ Industry Fixed } & Effects, Log \\
Additional Covariates & None & Effects & Employment \\
\hline \hline
\end{tabular}

Source: Bernard et al. (2007).

Notes: Data are for 2002 and are from the U.S. Census of Manufactures. All results are from bivariate OLS regressions of firm characteristic in first column on a dummy variable indicating firm's export status. Columns two and three include industry fixed effects and industry fixed effects plus log firm employment, respectively, as additional controls. Total factor productivity (TFP) is computed as in Caves et al (1982). Capital and skill per worker are capital stock and nonproduction workers per total employment, respectively. All results are significant at the 1 percent level. 
Table 3: Distribution of Exporters and Export Value by Number of Products and Export Destinations, 2000

\begin{tabular}{|c|c|c|c|c|c|c|}
\hline \multicolumn{7}{|c|}{ A. Share of Exporting Firms } \\
\hline \multirow{2}{*}{$\begin{array}{l}\text { Number of } \\
\text { Products }\end{array}$} & \multicolumn{5}{|c|}{ Number of Countries } & \multirow[b]{2}{*}{ All } \\
\hline & 1 & 2 & 3 & 4 & $5+$ & \\
\hline$\overline{1}$ & 40.4 & 1.2 & 0.3 & 0.1 & 0.2 & 42.2 \\
\hline 2 & 10.4 & 4.7 & 0.8 & 0.3 & 0.4 & 16.4 \\
\hline 3 & 4.7 & 2.3 & 1.3 & 0.4 & 0.5 & 9.3 \\
\hline 4 & 2.5 & 1.3 & 1.0 & 0.6 & 0.7 & 6.2 \\
\hline $5+$ & 6.0 & 3.0 & 2.7 & 2.3 & 11.9 & 25.9 \\
\hline All & 64.0 & 12.6 & 6.1 & 3.6 & 13.7 & 100.0 \\
\hline \multicolumn{7}{|c|}{ B. Share of Export Value } \\
\hline \multirow[t]{2}{*}{$\begin{array}{l}\text { Number of } \\
\text { Products } \\
\end{array}$} & \multicolumn{5}{|c|}{ Number of Countries } & \\
\hline & 1 & 2 & 3 & 4 & $5+$ & All \\
\hline 1 & 0.2 & 0.1 & 0.0 & 0.0 & 0.1 & 0.4 \\
\hline 2 & 0.2 & 0.1 & 0.0 & 0.0 & 0.1 & 0.5 \\
\hline 3 & 0.2 & 0.1 & 0.0 & 0.0 & 0.2 & 0.5 \\
\hline 4 & 0.1 & 0.1 & 0.1 & 0.0 & 0.3 & 0.6 \\
\hline$\underline{5+}$ & 2.6 & 1.2 & 1.0 & 0.9 & 92.2 & 98.0 \\
\hline All & 3.3 & 1.5 & 1.2 & 1.0 & 92.9 & 100.0 \\
\hline \multicolumn{7}{|c|}{ C. Share of Employment } \\
\hline \multirow[t]{2}{*}{$\begin{array}{l}\text { Number of } \\
\text { Products } \\
\end{array}$} & \multicolumn{5}{|c|}{ Number of Countries } & \\
\hline & 1 & 2 & 3 & 4 & $5+$ & All \\
\hline 1 & 7.0 & 0.0 & 0.0 & 0.0 & 0.0 & 7.1 \\
\hline 2 & 1.9 & 2.6 & 0.1 & 0.0 & 0.0 & 4.6 \\
\hline 3 & 1.3 & 1.0 & 0.8 & 0.0 & 0.2 & 3.3 \\
\hline 4 & 0.5 & 0.4 & 0.3 & 0.2 & 0.2 & 1.6 \\
\hline $5+$ & 3.5 & 2.6 & 4.3 & 4.1 & 68.8 & 83.3 \\
\hline All & 14.2 & 6.7 & 5.5 & 4.3 & 69.2 & 100.0 \\
\hline
\end{tabular}

Source: Bernard et al. (2007).

Notes: Data are from the 2000 LFTTD. Table displays the joint distribution of U.S. manufacturing firms that export (top panel), their export value (middle panel) and their employment (bottom panel), according to the number of products firms export (rows) and their number of export destinations (columns). Products are defined as ten-digit Harmonized System categories. 
Table 4: Gravity the Margins of Trade

\begin{tabular}{lc|cc|ccc}
\hline \hline & $\ln \left(\right.$ Value $\left._{c}\right)$ & $\ln \left(\right.$ Avg Exports $\left._{c}\right)$ & $\ln \left(\right.$ Obs $\left._{\mathrm{c}}\right)$ & $\ln \left(\right.$ Firms $\left._{\mathrm{c}}\right)$ & $\ln \left(\right.$ Products $\left._{\mathrm{c}}\right)$ & $\ln \left(\right.$ Density $\left._{\mathrm{c}}\right)$ \\
\hline $\ln \left(\right.$ Distance $\left._{\mathrm{c}}\right)$ & -1.37 & 0.05 & -1.43 & -1.17 & -1.1 & 0.84 \\
& 0.17 & 0.1 & 0.17 & 0.15 & 0.15 & 0.13 \\
$\ln \left(\mathrm{GDP}_{\mathrm{c}}\right)$ & 1.01 & 0.23 & 0.78 & 0.71 & 0.55 & -0.48 \\
& 0.04 & 0.02 & 0.04 & 0.03 & 0.03 & 0.03 \\
Constant & 7.82 & 6.03 & 1.8 & 0.52 & 3.48 & -2.2 \\
& 1.83 & 1.07 & 1.81 & 1.59 & 1.55 & 1.37 \\
\hline Observations & 175 & 175 & 175 & 175 & 175 & 175 \\
Fixed Effects & $\mathrm{No}$ & $\mathrm{No}$ & $\mathrm{No}$ & No & No & No \\
$\mathrm{R}^{2}$ & 0.82 & 0.37 & 0.75 & 0.76 & 0.68 & 0.66 \\
\hline \hline
\end{tabular}

Source: Bernard et al. (2011).

Notes: Table reports results of OLS regressions of U.S. export value or its components on tradingpartners' GDP and great-circle distance (in kilometers) from the United States. All five columns are country-level regressions. Heteroscedasticity robust standard errors are noted below each coeficient. Data are for 2002. 
Table 5: Trading Premia in U.S. Manufacturing, 1997

\begin{tabular}{lccc}
\hline \hline & $\begin{array}{c}\text { Exporter } \\
\text { Premia }\end{array}$ & $\begin{array}{c}\text { Importer } \\
\text { Premia }\end{array}$ & $\begin{array}{c}\text { Exporter \& } \\
\text { Importer } \\
\text { Premia }\end{array}$ \\
\hline Log Employment & 1.50 & 1.40 & 1.75 \\
Log Shipments & 0.29 & 0.26 & 0.31 \\
Log Value Added per Worker & 0.23 & 0.23 & 0.25 \\
Log TFP & 0.07 & 0.12 & 0.07 \\
Log Wage & 0.29 & 0.23 & 0.33 \\
Log Capital per Worker & 0.17 & 0.13 & 0.20 \\
Log Skill per Worker & 0.04 & 0.06 & 0.03 \\
\hline \hline
\end{tabular}

Source: Bernard et al. (2007)

Notes: Data are for 1997 and are for firms that appear in both the U.S. Census of Manufacturers and the LFTTD. All results are from bivariate OLS regressions of firm characteristic in first column on dummy variable noted at the top of each column as well as industry fixed effects and firm employment as additional controls. Employment regressions omit firm employment as a covariate. Total factor productivity (TFP) is computed as in Caves et al (1982). Capital and skill per worker are capital stock and non-production workers per total employment, respectively. All results are significant at the 1 percent level. 


\section{CENTRE FOR ECONOMIC PERFORMANCE \\ Recent Discussion Papers}

\begin{tabular}{|c|c|c|}
\hline 1083 & $\begin{array}{l}\text { Elisa Faraglia } \\
\text { Albert Marcet } \\
\text { Andrew Scott }\end{array}$ & In Search of a Theory of Debt Management \\
\hline 1082 & $\begin{array}{l}\text { Holger Breinlich } \\
\text { Alejandro Cuñat }\end{array}$ & A Many-Country Model of Industrialization \\
\hline 1081 & $\begin{array}{l}\text { Francesca Cornaglia } \\
\text { Naomi E. Feldman }\end{array}$ & $\begin{array}{l}\text { Productivity, Wages and Marriage: The Case } \\
\text { of Major League Baseball }\end{array}$ \\
\hline 1080 & Nicholas Oulton & $\begin{array}{l}\text { The Wealth and Poverty of Nations: True } \\
\text { PPPs for } 141 \text { Countries }\end{array}$ \\
\hline 1079 & $\begin{array}{l}\text { Gary S. Becker } \\
\text { Yona Rubinstein }\end{array}$ & $\begin{array}{l}\text { Fear and the Response to Terrorism: An } \\
\text { Economic Analysis }\end{array}$ \\
\hline 1078 & $\begin{array}{l}\text { Camille Landais } \\
\text { Pascal Michaillat } \\
\text { Emmanuel Saez }\end{array}$ & $\begin{array}{l}\text { Optimal Unemployment Insurance over the } \\
\text { Business Cycle }\end{array}$ \\
\hline 1077 & $\begin{array}{l}\text { Klaus Adam } \\
\text { Albert Marcet } \\
\text { Juan Pablo Nicolini }\end{array}$ & Stock Market Volatility and Learning \\
\hline 1076 & Zsófia L. Bárány & $\begin{array}{l}\text { The Minimum Wage and Inequality - The } \\
\text { Effects of Education and Technology }\end{array}$ \\
\hline 1075 & $\begin{array}{l}\text { Joanne Lindley } \\
\text { Stephen Machin }\end{array}$ & $\begin{array}{l}\text { Rising Wage Inequality and Postgraduate } \\
\text { Education }\end{array}$ \\
\hline 1074 & $\begin{array}{l}\text { Stephen Hansen } \\
\text { Michael McMahon }\end{array}$ & $\begin{array}{l}\text { First Impressions Matter: Signalling as a } \\
\text { Source of Policy Dynamics }\end{array}$ \\
\hline 1073 & Ferdinand Rauch & $\begin{array}{l}\text { Advertising Expenditure and Consumer } \\
\text { Prices }\end{array}$ \\
\hline 1072 & $\begin{array}{l}\text { Alberto Galasso } \\
\text { Mark Schankerman } \\
\text { Carlos J. Serrano }\end{array}$ & Trading and Enforcing Patent Rights \\
\hline 1071 & $\begin{array}{l}\text { Daniel Hale } \\
\text { John Coleman } \\
\text { Richard Layard }\end{array}$ & $\begin{array}{l}\text { A Model for the Delivery of Evidence-Based } \\
\text { PSHE (Personal Wellbeing) in Secondary } \\
\text { Schools }\end{array}$ \\
\hline 1070 & David Marsden & $\begin{array}{l}\text { Individual Voice in Employment } \\
\text { Relationships: A Comparison Under Different } \\
\text { Forms of Workplace Representation }\end{array}$ \\
\hline 1069 & $\begin{array}{l}\text { Ross Levine } \\
\text { Alexey Levkov } \\
\text { Yona Rubinstein }\end{array}$ & Racial Discrimination and Competition \\
\hline
\end{tabular}




\begin{tabular}{|c|c|c|}
\hline 1068 & $\begin{array}{l}\text { Klaus Adam } \\
\text { Albert Marcet }\end{array}$ & $\begin{array}{l}\text { Internal Rationality, Imperfect Market } \\
\text { Knowledge and Asset Prices }\end{array}$ \\
\hline 1067 & Yanhui Wu & $\begin{array}{l}\text { A Simple Theory of Managerial Talent, Pay } \\
\text { Contracts and Wage Distribution }\end{array}$ \\
\hline 1066 & Yanhui Wu & $\begin{array}{l}\text { Managerial Incentives and Compensation in a } \\
\text { Global Market }\end{array}$ \\
\hline 1065 & $\begin{array}{l}\text { Nicholas Bloom } \\
\text { Helena Schweiger } \\
\text { John Van Reenen }\end{array}$ & $\begin{array}{l}\text { The Land that Lean Manufacturing Forgot? } \\
\text { Management Practices in Transition } \\
\text { Countries }\end{array}$ \\
\hline 1064 & $\begin{array}{l}\text { Klaus Adam } \\
\text { Pei Kuang } \\
\text { Albert Marcet }\end{array}$ & House Price Booms and the Current Account \\
\hline 1063 & $\begin{array}{l}\text { Stephen Hansen } \\
\text { Michael McMahon }\end{array}$ & $\begin{array}{l}\text { How Experts Decide: Identifying Preferences } \\
\text { versus Signals from Policy Decisions }\end{array}$ \\
\hline 1062 & $\begin{array}{l}\text { Paul Dolan } \\
\text { Daniel Fujiwara } \\
\text { Robert Metcalfe }\end{array}$ & $\begin{array}{l}\text { A Step Towards Valuing Utility the Marginal } \\
\text { and Cardinal Way }\end{array}$ \\
\hline 1061 & $\begin{array}{l}\text { Marek Jarocinski } \\
\text { Albert Marcet }\end{array}$ & $\begin{array}{l}\text { Autoregressions in Small Samples, Priors } \\
\text { about Observables and Initial Conditions }\end{array}$ \\
\hline 1060 & $\begin{array}{l}\text { Christos Genakos } \\
\text { Kai Uwe Kühn } \\
\text { John Van Reenen }\end{array}$ & $\begin{array}{l}\text { Leveraging Monopoly Power by Degrading } \\
\text { Interoperability: Theory and Evidence from } \\
\text { Computer Markets }\end{array}$ \\
\hline 1059 & $\begin{array}{l}\text { Klaus Adam } \\
\text { Albert Marcet }\end{array}$ & Booms and Busts in Asset Prices \\
\hline 1058 & $\begin{array}{l}\text { Michael W. L. Elsby } \\
\text { Jennifer C. Smith } \\
\text { Jonathan Wadsworth }\end{array}$ & $\begin{array}{l}\text { The Role of Worker Flows in the Dynamics } \\
\text { and Distribution of UK Unemployment }\end{array}$ \\
\hline 1057 & Fabrice Defever & $\begin{array}{l}\text { Incomplete Contracts and the Impact of } \\
\text { Globalization on Consumer Welfare }\end{array}$ \\
\hline 1056 & Fadi Hassan & $\begin{array}{l}\text { The Penn-Belassa-Samuelson Effect in } \\
\text { Developing Countries: Price and Income } \\
\text { Revisited }\end{array}$ \\
\hline 1055 & $\begin{array}{l}\text { Albert Marcet } \\
\text { Ramon Marimon }\end{array}$ & Recursive Contracts \\
\hline
\end{tabular}

